\title{
The influence of innovation on international new ventures' exporting in Central and Eastern Europe and Central Asia countries
}

\author{
Krystian Bigos, Adam Michalik
}

\begin{abstract}
A B S T R A C T
Objective: The main objective of the article is to confirm the relationship between the innovativeness of new ventures and exporting. Based on the Oslo Manual, which indicates four main types of innovation, we analysed the innovation processes in firms and the impact of particular categories of innovation on export odds.

Research Design \& Methods: Apart from the literature review and its criticism, the article is based on data collected by the BEEPS, conducted among enterprises located in post-communist countries in Eastern Europe and Central Asia. After an appropriate selection procedure, 906 ventures were finally picked. For this purpose, five logit models were created to determine the chances for export, depending on the type of innovation implemented in each enterprise.
\end{abstract}

Findings: The likelihood of export in ventures is higher when it implements process and organisational innovations. Research results show that the implementation of organisational innovations by ventures increases the likelihood of export more than twice, while in the case of process innovations - about one and a half times.

Implications \& Recommendations: he importance of process and organisational innovations in ventures seems to play an important role in explaining the odds of their export. We recommend that future studies focus on explaining the lack of impact of product innovations and the negative relation of marketing innovations on the export propensity of ventures.

Contribution \& Value Added: The article enriches the ongoing scientific discourse on the role of innovation in determining the export odds of ventures.

\begin{tabular}{ll}
\hline Article type: & research article \\
& Innovation; export; international new ventures; international entre- \\
Keywords: & preneurship; internationalisation
\end{tabular}

JEL codes: F23, L26, O31

\section{Suggested citation:}

Bigos, K., \& Michalik, A. (2020). The influence of innovation on international new ventures' exporting in Central and Eastern Europe and Central Asia countries. Entrepreneurial Business and Economics Review, 8(3), 47-63. https://doi.org/10.15678/EBER.2020.080303 


\section{INTRODUCTION}

The globalisation of the business world leads to the shrinking of local markets. The development of a company based only on domestic recipients is increasingly impossible, which forces economic entities to apply more or less advanced forms of internationalisation. The Uppsala model, which assumes the gradual foreign expansion of enterprises (Johanson \& Vahlne, 1977), thus reflecting the business reality of the 1970s, increasingly often stands in contradiction with the activity of companies from the beginning thinking about the global market (McDougall, 1989; Knight \& Cavusgil, 2005; Maciejewski \& Wach, 2019). Often, the key success factor of these undertakings was the innovativeness of applied business solutions. In the literature, international new ventures (INVs) and high technology start-ups (known as international start-ups) have begun to gain popularity. There appeared increased attention on international new ventures, including export-oriented new ventures (Knight \& Kavusgil, 1996; Oviatt \& McDougall, 1994). These entities seek sources of competitive advantage in the international environment (McDougall, Shane, \& Oviatt, 1994). International new ventures achieve market success thanks to the high degree of innovation in their products and business models, along with the relatively high degree of internationalisation since the beginning of their existence.

Research conducted previously by others, although they indicate the existence of dependencies between the innovation and export of companies, due to the differences in the selection of the sample in terms of the country of origin, the size and type of activity cannot be reliable for international new ventures and should be continued. Therefore, we decided to choose as the subject of our research the dependence between particular types of innovation and export opportunities of INVs.

The development of the process of early internationalisation of small and mediumsized enterprises - called international new ventures or born globals - increased the number of studies on this phenomenon, but little is known about the stimulating factors and success factors of new international ventures from transition economies in Central and Eastern Europe (Vissak, 2006; Ciszewska-Mlinaric et al., 2016; Sekliuckiene, 2017; Sekliuckiene, Jarosinski, \& Kozma, 2019).

The main objective of the article is to confirm the relationship between the innovativeness of new ventures and exporting. The article consists of two parts: theoretical and empirical. In the first part, we conduct a critical analysis of literature, while in the empirical part we construe five models of logistic regression.

\section{LITERATURE REVIEW}

Oviatt and McDougall (1994) define International New Ventures (INV) as "a business organisation that, from inception, seeks to derive significant competitive advantage from the use of resources and the sale of output in multiple countries." They used two dimensions: applying the coordination of value chain activities (few vs many) and the number of countries involved (few vs many) to identify four types of INVs: export/important startups, multinational trader, geographically focused start-ups, and global start-ups.

INVs are characterised by rapid expansion into foreign markets but without a global presence (Sikora \& Baranowska-Prokop, 2018). Crick (2009) indicates that the terms "born 
global" and "international new venture" are used interchangeably to characterise companies that undergo rapid internationalisation "usually, but not exclusively, within three years of their start-up."

Schumpeter (1934) introduced the concept of innovation into economic literature, considering innovations to be solutions based on introducing new or improving existing solutions in terms of product, manufacturing methods, forms of trade, raw materials, and semi-finished products or the organisation of processes. According to Kotler (1997), innovation is an idea, a product, or an element of technology implemented and presented to customers who describe it as new. Lumpkin and Dess (2001), among others, point to innovation as one of the key elements of entrepreneurship at the company level.

Results of various empirical research show that the relationship between the firm's internationalisation process and the level of innovativeness of its solutions is twofold (Lachenmaier \& Wößmann, 2006; Damijan, Kostevc, \& Polanec, 2010; Wach, 2016; Moreno-Menéndez, 2018). In the first case, scholars analyse the impact of internationalisation on the growth of innovativeness of learning by exporting firms (e.g. Boso, Cadogan, \& Story, 2013; Nekethna \& Gunasekar, 2017; Aghion, Bergeaud, Lequien, \& Melitz, 2018). The second case gathers articles that examine the reverse relationship that shows the impact of innovation on the degree of internationalisation, which we will also discuss in this article (Chen, Chen, Wang, \& Xiang, 2018; Fassio, 2018).

Moreover, previous studies are not fully comparable due to differences in the size and market position of surveyed companies, their country of origin, or the area of business activity (van Beveren \& Vandenbussche, 2010). However, research conducted in particular markets unambiguously indicates the positive relationship between innovation and export development of individual enterprises. Cieślik, Qu, and Qu (2018) demonstrate a positive correlation between product and process innovations and chances for export success of Chinese companies. Similar conclusions are drawn by Cieślik and Michałek (2017a, 2017b, 2018), who cover, among other states, ECA countries and Visegrad countries; Bertarelli and Lodi (2018) base their research on companies from seven EU markets belonging in the past to the block of communist countries; while Tekin and Hancioğlu (2018) analyse companies from 17 developing countries. The pro-export significance of innovation is also demonstrated in the research conducted in the United Kingdom (Wakelin, 1998; Ganotakis \& Love, 2011), Slovenia (Damijan, Kostevc, \& Polanec, 2010), Portugal (Rua, 2018), Italy (Brancati, Marrocu, Romagnoli, \& Usai, 2018), Germany (Lachenmaier \& Wößmann, 2006; Bernardini Papalia, Bertarelli, \& Mancinelli, 2018), Belgium (van Beveren \& Vandenbussche, 2010), and Australia (Palangkaraya, 2012).

Using the example of Chilean companies, Blyde, Iberti, and Mussini (2018) indicate that the impact of innovation on exports is heterogeneous. The goods and markets in which innovative exporters outperform non-innovative exporters are those in which innovation can lead to substantial differences in terms of quality. Innovative firms do not have an edge in exporting goods and in targeting markets that do not reward innovation. Innovative firms do not outperform non-innovative firms when exporting goods and penetrating markets in which differentiation in terms of quality is impossible or irrelevant (Blyde, Iberti, \& Mussini, 2018).

The current research unambiguously indicates innovation as one of the determinants of a firm's success on export markets, mainly by analysing the importance of technological 
innovations, i.e. product and process innovations (Cavusgil \& Zhou, 1994; Wakelin, 1998; Roper, Love, 2002; Halpern, 2007; Wagner, 2007; Harris \& Li, 2009; Higón \& Driffield, 2011; Palangkaraya, 2012; Filipescu, Prashantham, Rialp, \& Rialp, 2013; Lewandowska, SzymuraTyc, \& Gołębiowski, 2016; Tavassoli, 2017; Movahedi, Shahbazi, \& Gaussens, 2017).

Based on the overview of prior studies in various parts of the globe and the OECD (2005) classification, we propose to verify the following research hypotheses:

H1: The implementation of product innovations by International New Ventures (INV) increases the export likelihood of a given INV.

H2: International New Ventures are more likely to export when they implement process innovations.

Less research focuses on non-technological innovations, i.e. marketing and organisational innovations (Damanpour \& Aravind, 2011; Morone, Renna, \& Testa, 2013; Crick \& Crick, 2015; Azar \& Ciabuschi, 2017).

However, the innovation process is complex, resulting from the pro-entrepreneurial orientation of managers and reflecting practically in every aspect of business activity, so that many researchers emphasise the importance of the complementarity of technological and non-technological innovations in terms of the impact on winning foreign markets (Lokshin, Gils, \& Bauer, 2010; Tidd \& Bessant, 2009; Azar \& Ciabuschi, 2017; Bodlaja, KadicMaglajlicb,\& Vidda, 2020).

Hence, we also anticipate the following:

H3: Organisational innovations implemented by International New Ventures increase the probability of their export.

H4: Marketing innovations implemented by International New Ventures increases the likelihood of exporting a given INV.

However, some studies do not confirm the link between innovation and exports. Results of research surveys by Ayllón and Radicic (2019) suggest complementarity only through contemporaneous effects but find no support for the causal link from past product and process innovations to current export activities. The study by Máñez-Castillejo, Rochina-Barrachina, and Sanchis-Llopis (2009) does not indicate this significant relationship.

\section{MATERIAL AND METHODS}

In this article, a binomial logistic regression model - also called the logit model - was applied. It is used to explain the dummy qualitative variable $Y$ depending on the level of independent (exogenous) variables $X_{1}, X_{2}, \ldots, X_{k}$ which, in turn, can be qualitative or quantitative. The dependent variable is a dummy (dichotomous) variable:

$$
Y=\left\{\begin{array}{lc}
1, & \text { phenomenon occurs } \\
0, & \text { otherwise }
\end{array}\right.
$$

In the logistic regression model, the binding function is known as logit and has the following form (Jackowska, 2011; McCullagh \& Nelder, 1989):

$$
g(p)=\operatorname{logit}(p)=\ln \left(\frac{p}{1-p}\right)
$$

Furthermore, the logistic regression model can be written in the following form: 


$$
p=P\left(Y=1 \mid X_{1}=x_{1}, X_{2}=x_{2}, \ldots, X_{k}=x_{k}\right)=\frac{\exp \left(\beta_{0}+\sum_{i=1}^{k} \beta_{i} x_{i}\right)}{1+\exp \left(\beta_{0}+\sum_{i=1}^{k} \beta_{i} x_{i}\right)}
$$

The estimation of model parameters $\beta_{1}, \beta_{2}, \ldots, \beta_{k}$ is usually performed with the use of the maximum likelihood method. The logarithm of the likelihood function with model parameters is maximised using iterative numerical procedures (Jackowska, 2011).

One of the advantages of the logistic regression model is the possibility of interpreting parameters $e^{\beta_{i}}$, which are defined as the ratio of the likelihood an event occurs to the probability that an event does not occur. In this model, the odds ratio can be expressed as a function of explanatory variables:

$$
\frac{p}{1+p}=\gamma\left(x_{1}, x_{2}, \ldots, x_{k}\right)=\exp \left(\beta_{0}+\sum_{i=1}^{k} \beta_{i} x_{i}\right)
$$

In the case of the constant term, the $e^{\beta_{0}}$ value is interpreted as the likelihood of a phenomenon occurring in the reference group (Jackowska, 2011).

The inference is based on data collected in the Business Environment and Enterprise Performance Survey (the BEEPS IV-V), ${ }^{1}$ which covered the years 2006-2014 and was conducted mainly among companies with headquarters in post-communist countries in Europe and Central Asia. Moreover, the BEEPS survey was conducted among companies with at least five employees, while the survey process itself was supported by several business organisations and government agencies responsible for promoting job creation and economic growth. In the BEEPS survey, questions were answered by business owners or senior managers in a face-to-face interview. The main objective of this survey was to obtain information from selected firms on the status of the private sector. The survey questions related, among others, to the identification of the enterprise in the sector (ownership structure), the determination of the legal and economic status of enterprises, the characteristics of management (e.g. education and professional experience).

The BEEPS survey asked respondents dichotomous questions about new or significantly improved innovations (i.e. product innovation, process innovation, organisational innovation, and marketing innovation). Each of the questions was preceded by a detailed explanation of what each type of innovation means. For instance, product innovations are understood as introducing new or significantly improved products or services. Moreover, they did not refer to minor changes and excluded products or services that effected from regular seasonal changes, routine improvements in functionality, and visual improvements that did not affect the functionality and resale of goods purchased from other companies.

The sample included SMEs operating in Central and Eastern Europe and Central Asia (31 countries altogether). Initially, nearly 10000 companies were selected for the analysis. Subsequently, those entities whose data were incomplete were eliminated. A spreadsheet was used to calculate the difference between the year of founding a business and the year of first foreign sales. In a second step, those firms with a difference of more than three years and foreign sales representing less than $25 \%$ of total sales were eliminated. This agrees with the criterion proposed by Jantunen, Nummela, Puumalainen, and Saarenketo (2008), Knight, Madsen, and Servais (2004), but also Madsen,

\footnotetext{
${ }^{1}$ The Business Environment and Enterprise Performance Survey is prepared by the European Bank for Reconstruction and Development and by the World Bank. The BEEPS IV-V panel dataset was last updated on 23 August 2017.
} 
Rasmussen, and Servais (2000). The sample also includes those ventures that did not have any foreign sales within three years of starting their business: 463 companies, which makes about $51 \%$ of the sample. Finally, 906 firms remained.

Table 1 presents the qualitative and quantitative variables included in the logit model. The dependent variable is the dummy variable EXPORT, which assigns value 1 when the venture sells abroad and value 0 when the venture does not sell abroad. The model also includes the control variables OWNERSHIP, EXPERIENCE, and R\&D SPENDING (see Table 1). Four types of innovation - product innovation, process innovation, organisational innovation, and marketing innovation - were adopted as independent variables, whose definitions are described in detail in the Oslo Manual. According to the third version of the publication, innovative activity means the entirety of scientific, technical, organisational, financial, and commercial activities that lead or are intended to lead to the implementation of innovation which, in turn, can be defined as the implementation of a new or significantly improved product, service, process, a new marketing method, or a new organisational method in business practice (OECD, 2005).

The Oslo Manual distinguishes between the following types of innovation (OECD, 2005):

- product innovations (NEW_PRODUCT): they concern the introduction of a product or service that is new or substantially improved in terms of its characteristics or use; such innovations include significant improvements in terms of technical specifications, components and materials, embedded software, user-friendliness, and other functional features,

- process innovations (NEW_PROCESS): they concern the implementation of a new or substantially improved production or supply method; such innovations include significant changes in the context of technology, equipment and software,

- organisational innovation (NEW_ORGANISATION): they are mainly the implementation of a new organisational method in the rules of operation adopted by the company in the organisation of the workplace or relations with the environment,

- marketing innovations (NEW_MARKETING): they are primarily the implementation of a new marketing method, which involves significant changes in the product design, packaging, distribution, promotion, or pricing strategy.

In the logit model, the independent variables describing particular types of innovations are dummy, e.g. in the context of product innovations, the independent variable assumes value 1 when a venture presented a new product/service over the last three years; otherwise, the variable assumes value 0 . The basic descriptive statistics are presented in Table 2. All the variables used in the model are zero-one variables, excluding the control variable EXPERIENCE that describes the professional experience of the owner of the venture (indicator measured by the number of years).

The sample included 906 ventures from 31 countries in Central and Eastern Europe and Central Asia (see Table 3). The largest groups were companies from Turkey (14.02\%), Georgia (7.17\%), and Tajikistan (7.06\%), while the smallest groups were the ventures from Montenegro (0.66\%), Slovakia (0.88\%), and Armenia (0.99\%). Among the countries currently belonging to the European Union, the largest number of enterprises came from Romania (4.42\%), Croatia (3.20\%), and Lithuania (3.09\%). 
Table 1. Variables used in the empirical analysis

\begin{tabular}{|l|l|}
\hline \multicolumn{1}{|c|}{ Variables } & \multicolumn{1}{c|}{ Description } \\
\hline EXPORT & Dummy variable that takes the value 1 if the venture is exporting and 0 if not. \\
\hline OWNERSHIP & $\begin{array}{l}\text { Dummy variable, that takes the value of } 1 \text { if at least 50\% of the shares in the } \\
\text { venture are held by a foreign investor, and 0 if not. }\end{array}$ \\
\hline EXPERIENCE & Number of years of professional experience of the venture owner. \\
\hline R\&D SPENDING & $\begin{array}{l}\text { Dummy variable that takes the value } 1 \text { if the venture spent on R\&D over the } \\
\text { last 3 years, otherwise } 0 .\end{array}$ \\
\hline NEW_PRODUCT & $\begin{array}{l}\text { Dummy variable that takes value } 1 \text { if the venture introduced new prod- } \\
\text { ucts/services over the last 3 years, otherwise 0. }\end{array}$ \\
\hline NEW_PROCESS & $\begin{array}{l}\text { Dummy variable that takes value } 1 \text { if the venture introduced new produc- } \\
\text { tion/supply methods over the last 3 years, otherwise 0. }\end{array}$ \\
\hline NEW_ORGANISATION & $\begin{array}{l}\text { Dummy variable that takes value 1 if the venture introduced new organisa- } \\
\text { tional/management practices or structures over the last 3 years, otherwise 0. }\end{array}$ \\
\hline NEW_MARKETING & $\begin{array}{l}\text { Dummy variable that takes value } 1 \text { if the venture introduced new marketing } \\
\text { methods over the last 3 years, otherwise 0. }\end{array}$ \\
\hline
\end{tabular}

Source: own study.

Table 2. Summary statistics

\begin{tabular}{|l|r|r|r|r|}
\hline \multicolumn{1}{|c|}{ Variables } & \multicolumn{1}{c|}{ Mean } & \multicolumn{1}{c|}{ SD } & Min & \multicolumn{1}{c|}{ Max } \\
\hline 1. EXPORT & 0.489 & 0.500 & 0 & 1 \\
\hline 2. OWNERSHIP & 0.088 & 0.284 & 0 & 1 \\
\hline 3. EXPERIENCE & 13.460 & 9.850 & 1 & 1 \\
\hline 4. R\&D SPENDING & 0.100 & 0.30 & 0 & 1 \\
\hline 5. NEW_PRODUCT & 0.231 & 0.422 & 0 & 1 \\
\hline 6. NEW_PROCESS & 0.174 & 0.380 & 0 & 1 \\
\hline 7. NEW_ORGANISATION & 0.191 & 0.393 & 0 & 1 \\
\hline 8. NEW_MARKETING & 0.216 & 0.412 & 0 & 0 \\
\hline
\end{tabular}

Source: own study.

Table 3. Countries of observations

\begin{tabular}{|l|r|r|}
\hline \multicolumn{1}{|c|}{ Country } & \multicolumn{1}{c|}{ Observations } & \multicolumn{2}{c|}{ Percentage } \\
\hline Albania & 53 & $5.85 \%$ \\
\hline Armenia & 9 & $0.99 \%$ \\
\hline Azerbaijan & 25 & $2.76 \%$ \\
\hline Belarus & 28 & $3.09 \%$ \\
\hline Bosnia and Herzegovina & 13 & $1.43 \%$ \\
\hline Bulgaria & 12 & $1.32 \%$ \\
\hline Croatia & 29 & $3.20 \%$ \\
\hline Cyprus & 12 & $1.32 \%$ \\
\hline The Czech Republic & 10 & $1.10 \%$ \\
\hline Estonia & 22 & $2.43 \%$ \\
\hline FYR Macedonia & 28 & $3.09 \%$ \\
\hline Georgia & 65 & $7.17 \%$ \\
\hline Greece & 26 & $2.87 \%$ \\
\hline Hungary & 19 & $2.10 \%$ \\
\hline Kazakhstan & 45 & $4.97 \%$ \\
\hline
\end{tabular}




\begin{tabular}{|l|r|r|}
\hline \multicolumn{1}{|c|}{ Country } & \multicolumn{1}{c|}{ Observations } & \multicolumn{2}{c|}{ Percentage } \\
\hline Kosovo & 24 & $2.65 \%$ \\
\hline The Kyrgyz Republic & 17 & $1.88 \%$ \\
\hline Latvia & 26 & $2.87 \%$ \\
\hline Lithuania & 28 & $3.09 \%$ \\
\hline Moldova & 13 & $1.43 \%$ \\
\hline Mongolia & 28 & $3.09 \%$ \\
\hline Montenegro & 6 & $0.66 \%$ \\
\hline Poland & 14 & $1.55 \%$ \\
\hline Romania & 40 & $4.42 \%$ \\
\hline Serbia & 28 & $3.09 \%$ \\
\hline The Slovak Republic & 8 & $0.88 \%$ \\
\hline Slovenia & 15 & $1.66 \%$ \\
\hline Tajikistan & 64 & $7.06 \%$ \\
\hline Turkey & 127 & $14.02 \%$ \\
\hline Ukraine & 30 & $3.31 \%$ \\
\hline Uzbekistan & 42 & $4.65 \%$ \\
\hline TOTAL & 906 & $100 \%$ \\
\hline
\end{tabular}

Source: own study.

\section{RESULTS AND DISCUSSION}

The program for statistical analysis Gretl (version 2018c) was used to construct five logistic regression models, in which the dependent variable is EXPORT, which assumes zero-one values; value 1 when venture realises foreign sales and value 0 when it does not realise foreign sales. Three control variables are included in the model: the first control dummy variable describes the ownership structure of the venture (OWNERSHIP), the second control variable (continuous variable) describes the number of years of professional experience of the venture owner (EXPERIENCE), and the third control variable concerns the R\&D expenditures of the company over the last three years (R\&D SPENDING).

The variables applied in the model are not strongly correlated with each other $(r<$ $0.5)$, so we can include them in the estimated regression model (see Table 4). Variance Inflation Factor (VIF) for independent variables in all models is less than 1.6 (see Table 5), which means that there is no collinearity between the variables. It is worth mentioning that VIF values greater than $5(1 / V I F<0.2)$ may indicate the problem of collinearity (Hair, 2006; Hair, Risher, Sarstedt, \& Ringle, 2018).

In the next step, the parameters of five logistic regression models were estimated, and coefficients are presented in Table 6 . To check the significance of variables in the models used, the likelihood-ratio test was conducted. The test showed the statistical significance of all models $(p<0.001)$. To avoid heteroscedasticity, the test included robust standard errors. The value of Pseudo-R2 depending on the model ranges from 0.0931 to 0.1118 .

All logit models clearly show that mainly the share of foreign capital and ventures' R\&D expenditures play a key role in increasing the likelihood of foreign sales. Nearly a six-times higher likelihood of export occurs when the share of foreign capital in the venture exceeds $50 \%$. The situation is similar in the case of expenditure on research and development. The likelihood of export occurrence is nearly twice higher in the case of those ventures, which 
allocate a part of their revenues to expenses related to research and development activity (see Table 6). These results are consistent with the research of other scientists (Kumar \& Siddharthan, 1994; Wagner, 1996; Zhao \& Li, 1997; Basile, 2001; Rodil, Vence, \& Sánchez, 2016; Cieślik, Michałek, \& Szczygielski, 2016; Cieślik \& Michałek, 2017a).

Table 4. Correlations matrix between variables

\begin{tabular}{|l|r|r|r|r|r|r|r|}
\hline \multicolumn{1}{|c|}{ Variables } & \multicolumn{1}{c|}{$\mathbf{1}$} & $\mathbf{2}$ & $\mathbf{3}$ & $\mathbf{4}$ & $\mathbf{5}$ & $\mathbf{6}$ & $\mathbf{7}$ \\
\hline 1. OWNERSHIP & 1.00 & & & & & & \\
\hline 2. EXPERIENCE & 0.04 & 1.00 & & & & & \\
\hline 3. R\&D SPENDING & 0.05 & 0.04 & 1.00 & & & & \\
\hline 4. NEW_PRODUCT & 0.13 & 0.10 & 0.34 & 1.00 & & & \\
\hline 5. NEW_PROCESS & 0.09 & 0.11 & 0.35 & 0.50 & 1.00 & & \\
\hline 6. NEW_ORGANISATION & 0.11 & 0.10 & 0.29 & 0.39 & 0.45 & 1.00 & \\
\hline 7. NEW_MARKETING & 0.07 & 0.08 & 0.28 & 0.42 & 0.38 & 0.50 & 1.00 \\
\hline
\end{tabular}

Significance of all indications: $p<0.05$.

Source: own calculations in Gretl.

Table 5. Multicollinearity test on variables

\begin{tabular}{|l|c|c|c|c|c|c|c|c|c|c|}
\hline \multirow{2}{*}{\multicolumn{1}{|c|}{ Variables }} & \multicolumn{2}{|c|}{ Model 1 } & \multicolumn{2}{c|}{ Model 2 } & \multicolumn{2}{c|}{ Model 3 } & \multicolumn{2}{c|}{ Model 4 } & \multicolumn{2}{c|}{ Model 5 } \\
\cline { 2 - 12 } & VIF & TOL & VIF & TOL & VIF & TOL & VIF & TOL & VIF & TOL \\
\hline 1. OWNERSHIP & 1.023 & 0.978 & 1.019 & 0.981 & 1.020 & 0.980 & 1.015 & 0.985 & 1.013 & 0.987 \\
\hline 2. EXPERIENCE & 1.019 & 0.981 & 1.012 & 0.988 & 1.016 & 0.984 & 1.017 & 0.983 & 1.013 & 0.987 \\
\hline 3. R\&D SPENDING & 1.214 & 0.824 & 1.131 & 0.884 & 1.188 & 0.842 & 1.185 & 0.844 & 1.123 & 0.890 \\
\hline 4. NEW_PRODUCT & 1.526 & 0.655 & 1.158 & 0.864 & 1.411 & 0.709 & & & & \\
\hline 5. NEW_PROCESS & 1.547 & 0.646 & & & 1.410 & 0.709 & 1.389 & 0.720 & & \\
\hline 6. NEW_ORGANISATION & 1.553 & 0.644 & & & & & 1.541 & 0.649 & 1.425 & 0.702 \\
\hline 7. NEW_MARKETING & 1.504 & 0.665 & & & & & 1.438 & 0.695 & 1.397 & 0.716 \\
\hline
\end{tabular}

"VIF values > 10.0" may indicate a collinearity problem.

Source: own calculations in Gretl.

Based on the first model of logistic regression (Table 6), we may conclude that the likelihood of export is 1.52 times higher in ventures that implement process innovations than in those that do not $(p<0.1)$. The same situation applies to organisational innovations. The implementation of organisational innovations in a given venture increases the likelihood of export slightly more than 2.5 times $(p<0.01)$. The situation of marketing innovations is somewhat different. In this case, the implementation of marketing innovations by ventures does not increase their likelihood of export $(p<0.05)$. The model omits the interpretation of the independent variable that describes product innovations because the estimated parameter of logistic regression is statistically insignificant.

In the next step, the logistic regression model (2) was constructed, in which - besides control variables - the independent variable NEW_PRODUCT was used. It turns out that when a venture implements product innovations, it increases the likelihood of its export 1.38 times than such if a venture would not implement innovations $(p<0.1)$. Taking into account also the results of model 1 estimation, it is not possible to unambiguously statistically confirm that product innovations are a key factor stimulating the export of a given 
venture. Therefore, there is no statistical basis for accepting hypothesis 1 , although we recommend further research in this direction. Nevertheless, the results of other cited studies and the logical thinking process indicate that the implementation of product innovations fosters an increase in product competitiveness, which is a factor facilitating the acquisition of new customers on the foreign market.

Model 3 includes two independent variables describing product innovation (NEW_PRODUCT) and process innovation (NEW_PROCESS). The results confirm hypothesis 2. Based on the model, we see that the implementation of process innovations in venture increases the probability of its export almost twice $(p<0.01)$. In the case of the independent variable describing product innovations, we may say that they do not affect the chance of export (no statistical significance).

In the next logistic regression model (4), three independent variables were taken into account: process innovation (NEW_PROCESS), organisational innovation (NEW_ORGANISATION), and marketing innovation (NEW_MARKETING). New organisational solutions in venture increase its likelihood of export 2.33 times than if the entity had not implemented them $(p<0.01)$, while process innovations increase its chance of export 1.5 times. The model seems to confirm hypothesis 3 that organisational innovations implemented by ventures increase the likelihood of export. The obtained results have their justification in a relatively little degree of the company's organisational development, which dominates in the case of a particular venture. Most frequently, these are entities with small organisational and human resources, hence innovations in this field have a significant impact on the development and export potential.

The last constructed logit model (5), which consists of two independent variables, i.e. a variable describing organisational innovations (NEW_ORGANISATION) and marketing innovations (NEW_MARKETING), was intended to confirm the thesis that the implementation of marketing innovations in a venture contributes to increasing the likelihood of export. It turns out that the likelihood of export in a venture does not increase when it implements marketing innovations. Moreover, taking into account the results obtained in the first and third model of logistic regression, we can finally reject hypothesis 4 , which states that the implementation of marketing innovations by venture increases the likelihood of their export.

This article contributes important insights to the relationship between innovativeness and new ventures exporting, further confirmed by studies conducted, among others, by Harris and Moffat (2011), Palangkaraya (2012), and Rodríguez and Rodríguez (2005). Salomon and Shaver (2005) argue that new ventures consider innovation to be the measurement of learning so that these ventures can strategically obtain access to foreign knowledge bases and increase their innovative potential by involvement in export operations. Moreover, Harris and Moffat (2011) maintain that R\&D spending in firms has a much greater impact on the likelihood of exports, which in turn is consistent with the results obtained in this study. In terms of process innovation, the results agree with research undertaken by Palangkaraya (2012) on Australian companies, which proves that process innovation plays an important role in the SMEs' export. This is because most product innovations concern products that are not new to the world, hence the greater significance of process innovations for SMEs. In our study, most companies belonged to the service sector, in which the majority of product innovations can happen outside of the company and, therefore, can be treated not as product innovations but process innovations (Palangkaraya, 2012). As far as organisational 
Table 6. Logistic regression model (exporter $=1$, non-exporter $=0$ )

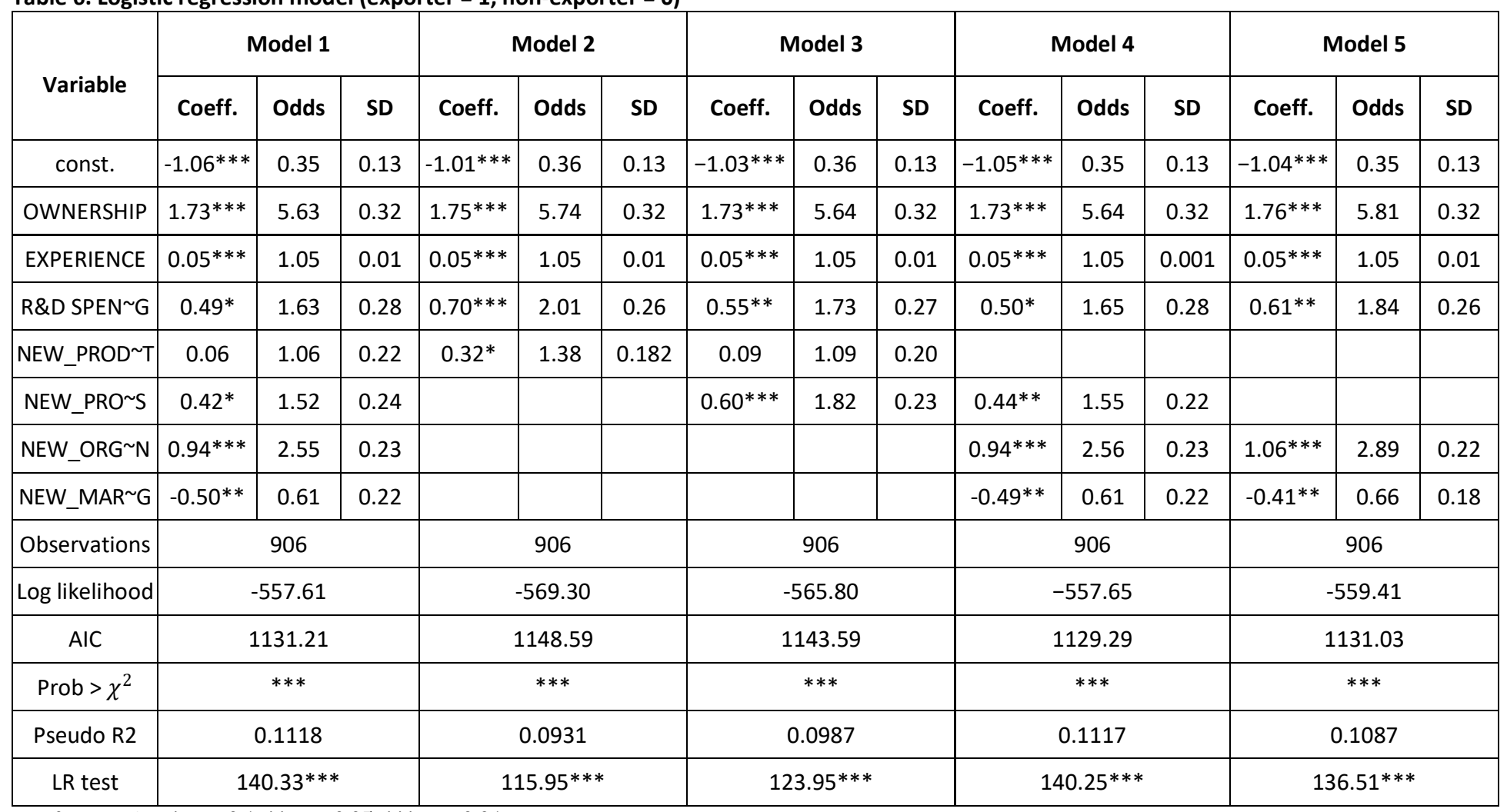

Significant codes: ${ }^{*} p<0.1,{ }^{* *} p<0.05,{ }^{* * *} p<0.01$.

Source: own calculations in Gretl. 
innovation is concerned, it is the significance for the company's export performance, which agrees with study results by Pino, Felzensztein, Zwerg-Villegas, and Arias-Bolzman (2016). The aforementioned relationship was confirmed on a sample of 299 entities from South America. In the case of marketing innovations, the analysis results presented a negative coefficient, which may suggest that marketing innovations are not significant for exporting. These results are in line with the studies of Cieślik and Michałek (2017b), but future research should explain the matter more thoroughly.

\section{CONCLUSIONS}

International ventures are characterised by a high degree of innovation. It is an expression of the general entrepreneurial orientation of managers, who strive to seek new solutions and continuous development of businesses. These activities will naturally be reflected in the choice of development path through expansion to new markets, therefore innovation and export orientation of venture are genetically linked to each other, although the degree of these links varies depending on the type of innovation.

The conducted research confirms two out of four hypotheses. Hypothesis 1 posited that the implementation of product innovations by venture increases the likelihood of their export, which has not been confirmed or rejected due to the lack of statistical significance. The logistic regression model confirmed hypotheses 2 and 3 . The implementation of process innovations in venture increases its likelihood of export almost 1.5 times, while in the case of organisational innovations -2.5 times. The last hypothesis was not confirmed. Based on data taken from the constructed logit model, it turns out that the implementation of marketing innovations in venture does not increase the likelihood of venture export $(p<0.05)$.

We obtained different results in the case of product innovations (no statistical significance). In terms of products from the very beginning, the reason may be the innovative nature of the surveyed ventures activities, causing the implemented subsequent product solutions to not generate significant changes in the likelihood of export.

As each empirical study, the current one is not free of its limitations. The research sample included SMEs strongly differentiated in terms of sector and industry, but also in size and country of capital origin. The analysis of the occurrence possibility of certain characteristics specific to ventures from a given country was not included, and the cause and effect relationships between the phenomenon of innovation and export in particular industries were not examined.

At present, there are not enough studies on the influence of ventures innovativeness on their export activities. It seems justified to take into account, among other things, the sectoral and industry diversification of venture activity as one of the variables influencing the export-oriented - or even global - attitude of managers towards export. It is worth considering complementing the results of quantitative research with qualitative research, which may deepen the research conclusions obtained so far.

\section{REFERENCES}

Aghion, Ph., Bergeaud, A., Lequien M., \& Melitz M.J. (2018). The Impact of Exports on Innovation: Theory and Evidence (NBER Working Papers, 24600). National Bureau of Economic Research, Inc. 
Ayllón, S., \& Radicic, D. (2019). Product innovation, process innovation and export propensity: Persistence, complementarities and feedback effects in Spanish firms. Applied Economics, 51(33), 3650-3664. https://doi.org/10.1080/00036846.2019.1584376

Azar, G., \& Ciabuschi, F. (2017). Organizational innovation, technological innovation, and export performance: The effects of innovation radicalness and extensiveness. International Business Review, 26(2), 324-336.

Basile, R. (2001). Export behaviour of Italian manufacturing firms over the nineties; the role of innovation. Research Policy, 30(8), 1185-1201.

Bernardini Papalia, R., Bertarelli, S., \& Mancinelli, S. (2018). Innovation, complementarity, and exporting. evidence from German manufacturing firms. International Review of Applied Economics, 32(1), 3-38. https://doi.org/10.1080/02692171.2017.1332576

Bertarelli, S., \& Lodi, C. (2018). Innovation and Exporting: A study on Eastern European Union Firms. Sustainability (Switzerland), 10(10). https://doi.org/10.3390/su10103607

Blyde, J., Iberti, G., \& Mussini, M. (2018). When does innovation matter for exporting? Empirical Economics, 54(4), 1653-1671. https://doi.org/10.1007/s00181-017-1274-x

Bodlaja, M., Kadic-Maglajlicb, S., \& Vidda, I. (2020). Disentangling the impact of different innovation types, financial constraints and geographic diversification on SMEs' export growth. Journal of Business Research, 108, 466-475.

Boso, N., Cadogan, J.W., \& Story, V.M. (2013). Entrepreneurial orientation and market orientation as drivers of product innovation success: A study of exporters from a developing economy. International Small Business Journal, 31(1), 57-81. https://doi.org/10.1177/0266242611400469

Brancati, R., Marrocu, E., Romagnoli, M., \& Usai, S. (2018). Innovation activities and learning processes in the crisis: Evidence from Italian export in manufacturing and services. Industrial and Corporate Change, 27(1), 107-130. https://doi.org/10.1093/icc/dtx022

Cassiman, B., Golovko, E., \& Martinez-Ros, E. (2010). Innovation, exports and productivity. International Journal of Industrial Organization, 28(4), 372-376.

Cavusgil, S.T., \& Zou, S. (1994). Marketing Strategy-performance Relationship: An Investigation of the Empirical Link in Export Market Ventures. Journal of Marketing 58(1), 1-21.

Chen, T., Chen, X., Wang, C., \& Xiang, X. (2018). Export Behavior and Firm Innovation: New Method and Evidence. Economics Letters, 170, 76-78. https://doi.org/10.1016/j.econlet.2018.05.029

Cieślik, A., \& Michałek, J.J. (2017a). Innovations and export performance of new EU member states. Ekonomista, 5, 489-505.

Cieślik, A., \& Michałek, J.J. (2017b). Innovation forms and firm export performance: Empirical evidence from ECA countries. Entrepreneurial Business and Economics Review, 5(2), 85-99. https://doi.org/10.15678/EBER.2017.050205

Cieślik, A., \& Michałek, J. J. (2018). Process and product innovations, multi-product status and export performance: firm-level evidence from V-4 countries. Equilibrium. Quarterly Journal of Economics and Economic Policy, 13(2), 233-250. https://doi.org/a10.24136/eq.2018.012

Cieślik, A., Michałek, J.J., \& Szczygielski, K. (2016). Innovations and export performance: Firm-level evidence from Poland. Entrepreneurial Business and Economics Review, 4(4), 11-28. https://doi.org/10.15678/EBER.2016.040402

Cieślik, A., Qu, Y., \& Qu, T. (2018). Innovations and Export Performance: Firm Level Evidence from China. Entrepreneurial Business and Economics Review, 6(4), 27-47.

Ciszewska-Mlinaric, M., Obloj, K., \& Wąsowska A. (2016). Effectuation and causation: Two decisionmaking logics of INVs at the early stage of growth and internationalisation. Journal of East European Management Studies, 21(4), 275-297. https://doi.org/10.5771/0949-6181-2016-3-275 
Crick, D. (2009). The internationalization of born global and international new venture SMEs. International Marketing Review, 26, 453-476.

Crick, D., \& Crick, J. (2015). The first export order: A marketing innovation revisited. Journal of Strategic Marketing, 24(2), 77-89. https://doi.org/10.1080/0965254X.2014.1001870

Damanpour, F., \& Aravind, D. (2011). Managerial Innovation: Conceptions, Processes, and Antecedents. Management and Organization Review, 8, 423-454.

Damijan, J.P., Kostevc, C., \& Polanec, S. (2010). From innovation to exporting or vice versa?. World Economy, 33(3), 374-398.

Fassio, C. (2018). Export-led innovation: The role of export destinations. Industrial and Corporate Change, 27(1), 149-171. https://doi.org/10.1093/icc/dtx028

Filipescu, D.A., Prashantham, S., Rialp A., \& Rialp, J. (2013). Technological Innovation and Exports: Unpacking Their Reciprocal Causality. Journal of International Marketing, 21(1), 23-38.

Ganotakis, P., \& Love, J.H. (2011). R\&D, Product Innovation, and Exporting: Evidence from UK New Technology based Firms. Oxford Economic Papers, 63(2), 279-306. https://doi.org/10.1093/oep/gpq027

Hair, J.F. (2006). Multivariate Data Analysis (6th ed.). Upper Saddle River, N.J.: Pearson Prentice Hall.

Hair, J.F., Risher, J.J., Sarstedt, M., \& Ringle, C.M. (2018). When to Use and How to Report the Results of PLS-SEM. European Business Review, 31(3), 2-24. https://doi.org/https://doi.org/10.1108/EBR-11-2018-0203.

Halpern, L. (2007). Literature Survey on the Links between Innovation, Competition, Competitiveness, Entry \& Exit, Firm Survival and Growth, Micro-dyn, EU Sixth Framework Programme (Working Paper No. 02/07).

Harris, R., \& Li, Q.C. (2009). Exporting, R\&D, and Absorptive Capacity in UK Establishments. Oxford Economic Papers, 61(1), 74-103.

Harris, R., \& Moffat, J. (2011). R\&D, innovation and exporting (No. 33593). London School of Economics and Political Science, LSE Library.

Higón, D.A., \& Driffield, N. (2011). Exporting and innovation performance: Analysis of the annual small business survey in the UK. International Small Business Journal, 29(1), 4-24.

Jackowska, B. (2011). Efekty interakcji między zmiennymi objaśniającymi w modelu logitowym w analizie zróżnicowania ryzyka zgonu. Przeglqqd Statystyczny, 58(1-2), 24-41.

Jantunen, A., Nummela, N., Puumalainen, K., \& Saarenketo, S. (2008). Strategic Orientations of Bornglobals - Do They Really Matter?. Journal of World Business, 43(2), 158-170.

Johanson J., \& Vahlne J.E. (1977). The Internationalization Process of the Firm: a Model of Knowledge Development and Increasing Foreign Market Commitments. Journal of International Business Studies, 8(1), 23-32.

Knight, G.A., \& Cavusgil, S.T. (1996). The born global firm: A challenge to traditional internationalization theory. In S.T. Cavusgil \& T.K. Madsen (Eds.), Export internationalizing research-enrichment and challenges (Advances in International Marketing Series, Vol. 8, pp. 11-26). New York: JAI.

Knight, G.A., \& Cavusgil S.T. (2005). A Taxonomy of Born-Global Firms. Management International Review, 45(3), 15-35.

Knight, G., Madsen, T.K., \& Servais, P. (2004). An Inquiry into Born-global Firms in Europe and the USA. International Marketing Review, 21(6), 645-665. https://doi.org/10.1108/02651330410568060

Kotler, Ph. (1997). Marketing Management - Analysis, Planning, Implementation, and Control. NJ: Prentice Hall. 
Lachenmaier, S., \& Wößmann, L. (2006). Does Innovation Cause Exports? Evidence from Exogenous Innovation Impulses and Obstacles using German Micro Data. Oxford Economic Papers, 58(2), 317-350. https://doi.org/10.1093/oep/gpi043

Lewandowska, M.S., Szymura-Tyc, M., \& Gołebiowski, T. (2016). Innovation Complementarity, Cooperation Partners, and New Product Export: Evidence from Poland. Journal of Business Research, 69(9), 3673-3681. https://doi.org/10.1016/j.jbusres.2016.03.028

Lumpkin, G.T., \& Dess, G.G. (2001). Linking two dimensions of entrepreneurial orientation to firm performance: the moderating role of environment and industry life cycle. Journal of Business Venturing, 16(5), 429-451.

Maciejewski, M., \& Wach, K. (2019). International Startups from Poland: Born Global or Born Regional? Journal of Management and Business Administration. Central Europe, 27(1), 60-83.

Madsen, T.K., Rasmussen, E., \& Servais, P. (2000). Differences and Similarities between Born-globals and other Types of Exporters. In: A. Yaprak \& H. Tutek (Eds), Globalization, the Multinational Firm, and Emerging Economies (pp. 247-265). Amsterdam: Emerald Group Publishing.

Máñez-Castillejo, J., Rochina-Barrachina, M., \& Sanchis-Llopis, J. (2009). Self-selection into Exports: Productivity and/or Innovation? Applied Economics Quarterly, 55(3), 219-241.

McCullagh, P., \& Nelder, J.A. (1989). Generalized Linear Models. Boston, US: Springer.

McDougall, P. (1989). International versus Domestic Entrepreneurship: New Venture Strategic Behavior and Industry Structure. Journal of Business Venturing, 4(6), 387-400.

McDougall, P., Shane S., \& Oviatt, B. (1994). Explaining the Formation of International New Ventures: The Limits of Theories from International Business Research. Journal of Business Venturing, 9(6), 469-487.

Moreno-Menéndez, A.M. (2018). Co-Evolution of Innovation Cooperation Activities and Internationalisation through Exports. Innovation: Management, Policy and Practice, 20(4), 353-376. https://doi.org/10.1080/14479338.2018.1502611

Morone, P., Renna, F., \& Testa, G. (2013). Innovation Activities and Italian SMEs' Exports Decisions: A Multi-treatment Analysis. International Journal of Globalisation and Small Business, 5(4), 256272. https://doi.org/10.1504/IJGSB.2013.056810

Movahedi, M., Shahbazi, K., \& Gaussens, O. (2017). Innovation and Willingness to Export: Is There an Effect of Conscious Self-selection?. Economics, 11, 1-22. https://doi.org/10.5018/economicsejournal.ja.2017-25

Nekethna, M.S., \& Gunasekar, S. (2017). Export Behaviour and Innovation - A Tobit Analysis (Paper presented at the 2016 IEEE International Conference on Computational Intelligence and Computing Research, ICCIC 2016). https://doi.org/10.1109/ICCIC.2016.7919690

OECD. (2005). Oslo Manual: Guidelines for Collecting and Interpreting Innovation Data (3ed.). Paris: OECD. Retrieved from http://dx.doi.org/10.1787/9264013105 on June 15, 2019.

Oviatt, B.M. \& McDougall, P.P. (1994). Toward a theory of international new ventures. Journal of International Business Studies, 25(1), 45-64.

Palangkaraya, A. (2012). The Link between Innovation and Export: Evidence from Australia's Small and Medium Enterprises. ERIA Discussion Paper Series, 8, 1-41.

Pino, C., Felzensztein, C., Zwerg-Villegas, A.M., \& Arias-Bolzman, L. (2016). Non-technological innovations: Market performance of exporting firms in South America. Journal of Business Research, 69(10), 4385-4393.

Rodil, Ó., Vence, X., \& Sánchez, M.D.C. (2016). The relationship between innovation and export behaviour: The case of galician firms. Technological Forecasting and Social Change, 113, 248-265. https://doi.org/10.1016/j.techfore.2015.09.002 
Rodríguez, J.L., \& Rodríguez, R.M.G. (2005). Technology and export behaviour: a resource-based view approach. International Business Review, 14(5), 539-557.

Roper, S., \& Love, J.H. (2002). Innovation and Export Performance: Evidence from the UK and German Manufacturing Plants. Research Policy, 31(7), 1087-1102.

Rua, O.L. (2018). From Intangible Resources to Export Performance: Exploring the Mediating Effect of Absorptive Capabilities and Innovation. Review of International Business and Strategy, 28(34), 373-394. https://doi.org/10.1108/RIBS-02-2018-0012

Salomon, R.M., \& Shaver, J.M. (2005). Learning by Exporting: New Insights from Examining Firm Innovation. Journal of Economics and Management Strategy, 14, 431-460.

Schumpeter, J. (1934). The Theory of Economic Development. Cambridge: Harvard University Press.

Sekliuckiene, J. (2017). Factors leading to early internationalization in emerging Central and Eastern European economies: Empirical evidence from new ventures in Lithuania. European Business Review, 29(2), 219-242. https://doi.org/10.1108/EBR-12-2015-0158

Sekliuckiene, J., Jarosinski, M., \& Kozma, M. (2019). Entrepreneurial Level Factors of Early Internationalization: a Cross Country Comparison. Inzinerine Ekonomika - Engineering Economics, 30(2), 223-235.

Sikora, T., \& Baranowska-Prokop, E. (2018). Explaining success perception of Polish international new ventures: Four perspectives. Economics and Sociology, 11(4), 106-127. https://doi.org/10.14254/2071-789X.2018/11-4/7

Tavassoli, S. (2017). The Role of Product Innovation on Export Behavior of Firms: Is it Innovation Input or Innovation Output that Matters?. European Journal of Innovation Management 21(2), 294-314. https://doi.org/10.1108/EJIM-12-2016-0124

Tekin, E., \& Hancioğlu, Y. (2018). The Effects of Innovation on Export Performance in Developing Countries. Global issues in social sciences: Different perspectives - multidisciplinary approaches, 23-36. https://doi.org/10.3726/ b13343

Tidd, J., \& Bessant, J. (2009). Managing Innovation: Integrating Technological, Market and Organizational Change. Chichester: Wiley.

van Beveren, I., \& Vandenbussche, H. (2010). Product and Process Innovation and Firms' Decision to Export. Journal of Economic Policy Reform, 13(1), 3-24. https://doi.org/10.1080/17487870903546267

Vissak, T. (2006). Internationalisation of Estonian Listed Companies - Theories and Reality. In T. Mets, J. Andrijevskaja, U. Venesaar, \& E. Kolbre (Eds.), Entrepreneurship in Estonia: policies, practices, education and research (pp. 116-138). Tartu: University of Tartu.

Wach, K. (2016). Innovative Behaviour of High-Tech Internationalized Firms: Survey Results from Poland. Entrepreneurial Business and Economics Review, 4(3), 153-165.

Wagner, J. (1996). Export Performance, Human Capital, and Product Innovation in Germany. A Micro View. Jahrbuch für Wirtschaftswissenschaften, 47, 40-45.

Wagner, J. (2007). Exports and Productivity: a Survey of the Evidence from Firm-level Data. World Economy, 30(1), 60-82.

Wakelin, K. (1998). Innovation and Export Behaviour at the Firm Level. Research Policy, 26(7-8), 829-841. 


\section{Authors}

The contribution share of authors is equal and amounted to $50 \%$ each of them.

\section{Krystian Bigos ${ }^{1}$}

Research Assistant at Cracow University of Economics, Department of International Trade at the College of Economics, Finance and Law. His research interests include early and rapid internationalisation, international start-ups and international entrepreneurship.

Correspondence to: Krystian Bigos, MSc, Department of International Trade, Cracow University of Economics, Poland, e-mail: bigosk@uek.krakow.pl

ORCID (ㄴ) http://orcid.org/0000-0001-6030-4119

\section{Adam Michalik 2}

Assistant Professor at Cracow University of Economics, Department of International Trade at the College of Economics, Finance and Law. His research interests include entrepreneurship, foreign investments, and security of business transactions.

Correspondence to: Adam Michalik, PhD, Department of International Trade, Cracow University of Economics, Poland, e-mail: michalia@uek.krakow.pl

ORCID (ㄱ) http://orcid.org/0000-0002-9333-408X

\section{Acknowledgements and Financial Disclosure}

The authors would like to thank the anonymous referees for their useful comments, which allowed to increase the value of this article.

${ }^{1}$ The article came into being within the PRELUDIUM-18 project entitled 'The Role of Intellectual and Financial Capital in the Early and Rapid Internationalisation of Polish startups', at the College of Economics, Finance and Law of Cracow University of Economics. The project was financed from the funds of the National Science Centre, Poland (NCN) granted on the base of the decision number DEC-2019/35/N/HS4/02832.

${ }^{2}$ This article is a part of a research project financed from the funds allocated to Cracow University of Economics within the framework of grants for maintaining research potential.

\section{Copyright and License}

This article is published under the terms of the Creative Commons Attribution - NoDerivs (CC BY-ND 4.0) License http://creativecommons.org/licenses/by-nd/4.0/

Published by Cracow University of Economics - Krakow, Poland 
